\title{
TREE (Transitions from Education to Employment): A Swiss Multi-Cohort Survey
}

\author{
Andrés Gomensoro \\ TREE, University of Bern, Switzerland \\ andres.gomensoro@soz.unibe.ch \\ Thomas Meyer \\ TREE, University of Bern, Switzerland
}

(Received August 2016

Revised February 2017)

http://dx.doi.org/10.14301/Ilcs.v8i2.424

\section{Abstract}

TREE (Transitions from Education to Employment) is a Swiss nationwide longitudinal study that follows two cohorts of compulsory school leavers throughout their transitions from education to employment and middle adulthood. To date, the first cohort survey (initial $N=6,343$ ) based on the Swiss PISA 2000 sample has covered a 14-year period from age 15 to 29 (nine follow-up surveys). The second cohort survey started in 2016 (with one follow-up survey in spring 2017 so far; initial $N=9,762$ ) and is based on a large national representative sample of students $(N=22,378)$ who sat a mathematics test at the end of the ninth grade (approximately 15 years old). TREE is designed to provide comprehensive data for the analysis of post-compulsory education, employment and other pathways (e.g. family and household situation, income/financial situation, critical life events, social integration and participation, psycho-social personal characteristics, health and wellbeing). As a social science infrastructure project of national and international importance, its data is freely available to the scientific community at large. This paper provides an overview of the TREE study with a specific focus on the latest data release (September 2016) for the first TREE cohort.

\section{Keywords}

Education, occupation, pathways, cohort survey, longitudinal research, PISA, Switzerland, life course

\section{Introduction}

Transitions from Education to Employment (TREE) is a unique and innovative multi-user, multicohort survey in Switzerland that follows two large representative samples $(>6,000$ respondents each) of compulsory school leavers throughout their transitions from education to employment and middle adulthood." The TREE survey has an interdisciplinary approach and covers a wide range of topics. The first cohort survey (TREE1) started in 2000 on the basis of the Swiss sample that participated in the Programme for International Student Assessment (PISA) and has since followed individuals from an average age of 15 to 29 (another panel wave is planned at an average age of
34). The second cohort (TREE2) was launched in 2016 and is based on a large sample of ninth graders who underwent a standardised national mathematics test at the end of their compulsory schooling. With this extension to a multi-cohort design, Switzerland will be among the few countries in the world in which comparative inter-cohort analyses can be carried out. As one of Switzerland's major social science data infrastructure projects, TREE is mainly funded by the Swiss National Science Foundation (SNF). The TREE1 data are among the country's most widely used datasets. As of 2014, the project has been located at the Institute of Sociology and the Institute of Educational Science at the University of Bern. 
This study profile aims to introduce the main design features of the TREE survey and to provide information on the latest data release (September 2016) for the first TREE cohort (TREE1), which is available free of charge for researchers in Switzerland and abroad (www.forscenter.ch). First, we focus on the survey's origin and its main objectives. Second, we describe the multi-cohort design and sampling procedure, data collection methods and samples, response rates and weighting. Finally, we introduce the survey content and data use of the TREE1 sample.

\section{Origin and objectives of TREE}

The TREE survey was launched in response to a recommendation the OECD made for Switzerland after its international review of transitions from initial education to working life (TIEW). Looking at the country report for Switzerland, which revealed substantial research gaps on the subject matter, the OECD expert committee noted:

"The opportunity should not be missed to equip Switzerland with a longitudinal survey of transitions at national level [...]. Transition pathways to employment are becoming increasingly complex. To understand young people's decisions and options, and to take them into account in policy decisions, appropriate analytical instruments are needed." (OECD, 1999:53)

The first TREE cohort survey was the empirical answer to this recommendation. In 2000, Switzerland participated in the first PISA study, which was designed to assess general literacy skills (main focus on reading) among students who have reached the end of compulsory school (age $15 /$ ninth grade). Along with Canada and Denmark, Switzerland has been the only participating country to follow the respondents of its PISA 2000 sample on their pathways through post-compulsory education and training and their transition to the labour market and to adult life.iii Since then, the TREE survey has become one of Switzerland's major social science data infrastructure projects (see later sections for detailed information on sampling procedures, data collection methods, response rates, attrition and weighting).

Four main objectives guide the TREE survey. First, TREE aims to precisely describe postcompulsory educational and employment transitions and pathways at the national and regional levels. With the continuation of the survey over the years, TREE1 has been gradually enlarging the perspective and scope of cohort observation into the "middle age" life phase. With the last survey panel carried out in 2014, the overall span of observation had reached almost 15 years, and another survey wave is scheduled in 2019 (at an average age of 34 ; see figure 1 ). Later transitions such as those from tertiary education to work or the consolidation of work careers can thus be studied in detail. In addition, the long observation period opens up new opportunities for conducting life-course research on the crossover effects of various life domains; for instance, social relations, education/career, family, psycho-social and physical health, socio-political integration, and commitment and attitudes.

Second, TREE aims to explain transitions and trajectories. Its context-rich data allow researchers to analyse explanatory factors such as socioeconomic and socio-cultural background, skills and academic achievement, personality traits, career ambitions as well as features of the school environment at the end of compulsory education and education/employment careers pursued thereafter. PISA 2000 is an excellent baseline survey for TREE. To begin with, it is a large, nationally representative sample of school leavers in Switzerland. Standardised skills measures as well as school and student characteristics at the end of compulsory school can therefore be linked to later educational outcomes and other life-domain trajectories. Moreover, by extending TREE to a multi-cohort survey (TREE2 started in 2016), Switzerland will be equipped with large-scale representative multi-cohort data on school-to-work and early life-course transitions, thereby allowing the study of specific cohort or systemic effects such as economic cycles, demographic trends or major reforms of the education system.

Third, TREE aims to provide longitudinal datasets to Swiss and international scholars along with a selection of key findings that can serve as a reference base for further in-depth analyses (see, e.g. Bergman, Hupka-Brunner, Keller, Meyer \& Stalder 2011; Scharenberg, Hupka-Brunner, Meyer \& Bergman 2016; Scharenberg, Rudin, Müller, Meyer \& Hupka-Brunner 2014).

Fourth, data provided by TREE also contribute to a better understanding of transitions for policymakers, educational and economic 
stakeholders, teaching and counselling staff, civil society actors and so forth.

\section{Overall design}

TREE follows two nationally representative cohort samples of compulsory school leavers at an interval of 16 years, both starting at approximately age 15 (see figure 1). The first cohort (TREE1) is based on a sample of 6,343 ninth graders who participated in the PISA test in spring 2000 and left compulsory school shortly thereafter. As mentioned above, the TREE1 sample is defined as a subset of PISA 2000 respondents (PISA $2000 N=13,463$; see Sacchi 2011, Renaud, 2002 and Adams \& Wu, 2002 for detailed information on the PISA 2000 sample in
Switzerland). The TREE1 sample includes all participants of PISA 2000 who

- had attended a regular public school at the lower secondary level at the time of the PISA survey; iv $^{2}$

- had completed ninth grade and left compulsory education at the end of the 1999/2000 school year;

- had agreed to participate in the TREE survey.

The TREE1 sample was surveyed nine times between 2001 and 2014, up to 2007 at yearly intervals. A tenth follow-up survey is planned for 2019 , by which time the sample will have reached an average age of approximately 34 (see figure 1).

Figure 1: TREE multi-cohort design 2000-2020 (TREE 2016b)

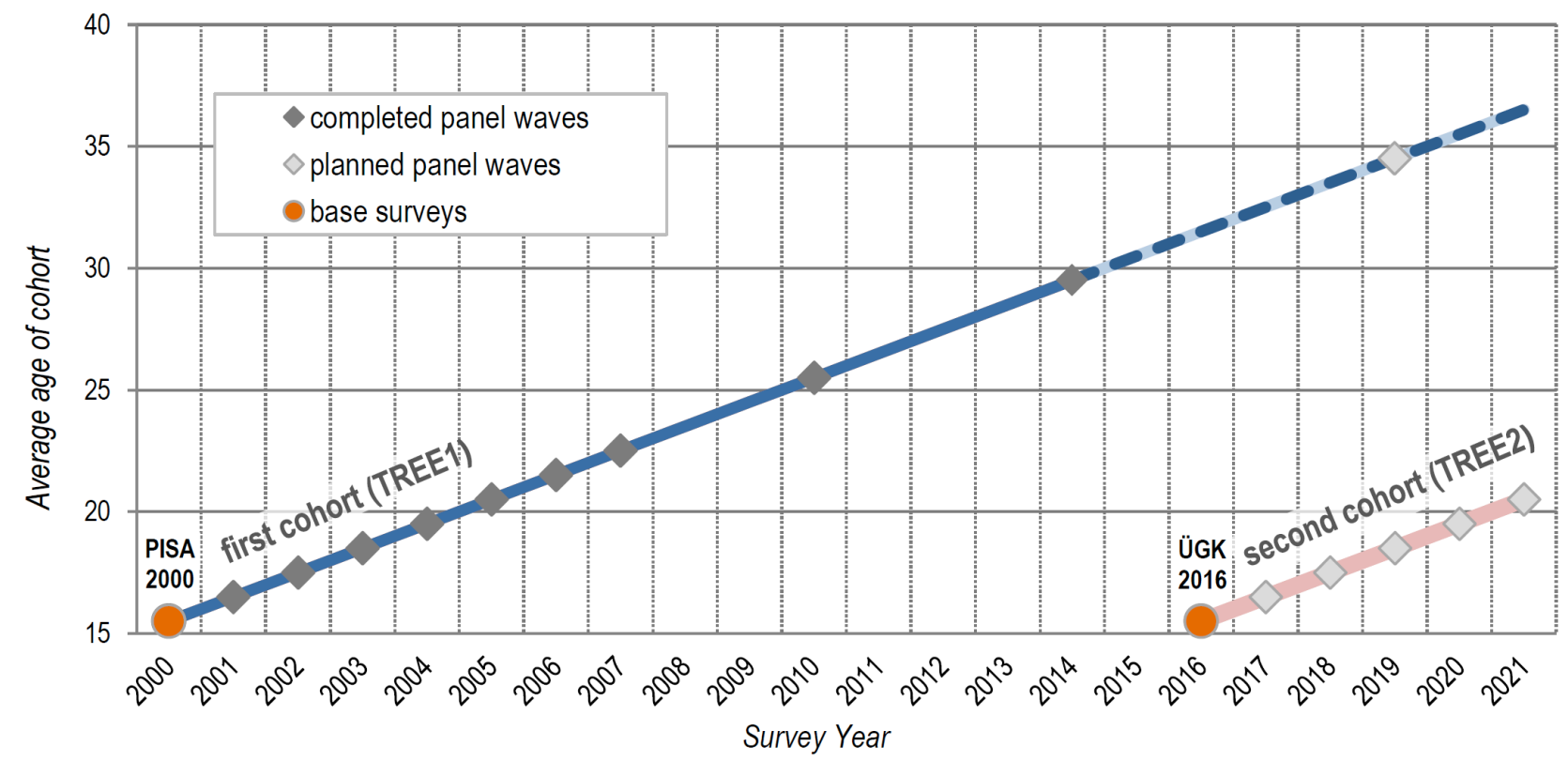

ÜGK 2016 = Acronym for Swiss National Mathematics Skills Assessment 2016

The second cohort survey (TREE2) was launched in 2016. It is based on a national large-scale assessment (LSA) in mathematics ${ }^{v}$ carried out among more than one-quarter of all ninth graders in Switzerland (gross sample $\approx 25,000$, response rate $92 \%$, average age 15$)$. The sample is representative of both national and cantonal levels. ${ }^{\text {vi }}$ TREE was granted permission to ask for the tested students' consent to be contacted for the TREE2 follow-up survey, and if so, for them to provide contact information. Close to 14,000 students agreed to be contacted (over $60 \%$ of all 2016 math LSA respondents). The TREE2 survey design essentially follows that of TREE1 for reasons of comparability. As with TREE1, the TREE2 sample is to be surveyed at annual intervals at its initial stage. The initial data will be publicly available by early 2019. Given that TREE2 has only just started and that so far only data on the first cohort is available to researchers, the following sections mainly focus on TREE1. 


\section{TREE1 survey design}

The TREE1 panel waves were invariably carried out toward the end of the Swiss school year (i.e., between February and June); the first four (20012004) were conducted mostly by mail (standardised written questionnaires). ${ }^{\text {vii }}$ Non-respondents were first reminded by mail and, if necessary, a second time by telephone (see the survey flowchart in figure 2). Respondents unable or unwilling to complete the written questionnaire were offered the opportunity to reply by means of a telephone interview as a secondary method. ${ }^{\text {viii }}$

Starting with panel wave five, the survey design shifted to a mixed-mode design that relied on a combination of computer-assisted telephone interviewing (CATI) and complementary written questionnaires tailored to specific education, training or job situations so as to accommodate the growing diversity of individual education and employment careers (see figure 2). The CATI interviews mainly collected episodic data on education and employment situation and history. The complementary questionnaire, sent out immediately after each CATI interview, aimed to gather in-depth descriptions and assessments of the principal activity (usually education or employment) specified in the CATI interview. CATI data were used to determine which type of supplementary written questionnaire would be sent to respondents. Respondents who could not be reached or who refused to answer questions by telephone were sent a written questionnaire as an alternative option. At each stage of the survey, non-responses were followed up by at least one reminder. The duration of the CATI interview ranged from 20 to 30 minutes; ${ }^{i x}$ filling out the complementary written questionnaire required another 20 minutes. As a general rule, total survey time per respondent (both interview and self-administered questionnaire) was not to exceed one hour. ${ }^{x}$

\section{Measures to increase panel retention}

With regard to panel maintenance and retention, TREE1 has adopted a strategy that relies on respondents' intrinsic motivation (i.e. to generally abstain from offering incentives). Measures to minimise attrition/maximise sample retention under this general strategy have included the following:

- Provision of alternative response modes, including short versions of the questionnaire, in order to lower the threshold for participation.

- Continuous extensive follow-up and update of respondents' contact information.

- From 2003 on, respondents began receiving a newsletter a few weeks prior to each survey that informed them about new results, publications and news related to the project. ${ }^{\mathrm{xi}}$ These newsletters, carefully customised to the target audience both linguistically and visually (layout), contributed not only to encouraging participation but also to updating respondents' contact data.

- Hotlines were installed for all three survey languages (German, French and Italian), which respondents could contact at any time during the field phase.

- Comprehensive interviewer training, including strategies on how to convince respondents to participate.

- In five of the nine waves, custom TREE ballpoint pens were included with the questionnaires as a small symbolic incentive and for the practical purpose of completing them.

- Regularly updated pages in all survey languages expressly addressing respondents on the project website (www.tree.unibe.ch).

- TREE has regularly made an effort to communicate to the respondents that their participation is not only of great importance but indeed indispensable to the project.

- Carefully individualised and immediate response to suggestions, criticism and questions voiced by the respondents, assuring them that their feedback is taken seriously. 
Figure 2: TREE1 survey design, 2000-2014 (TREE 2016b)

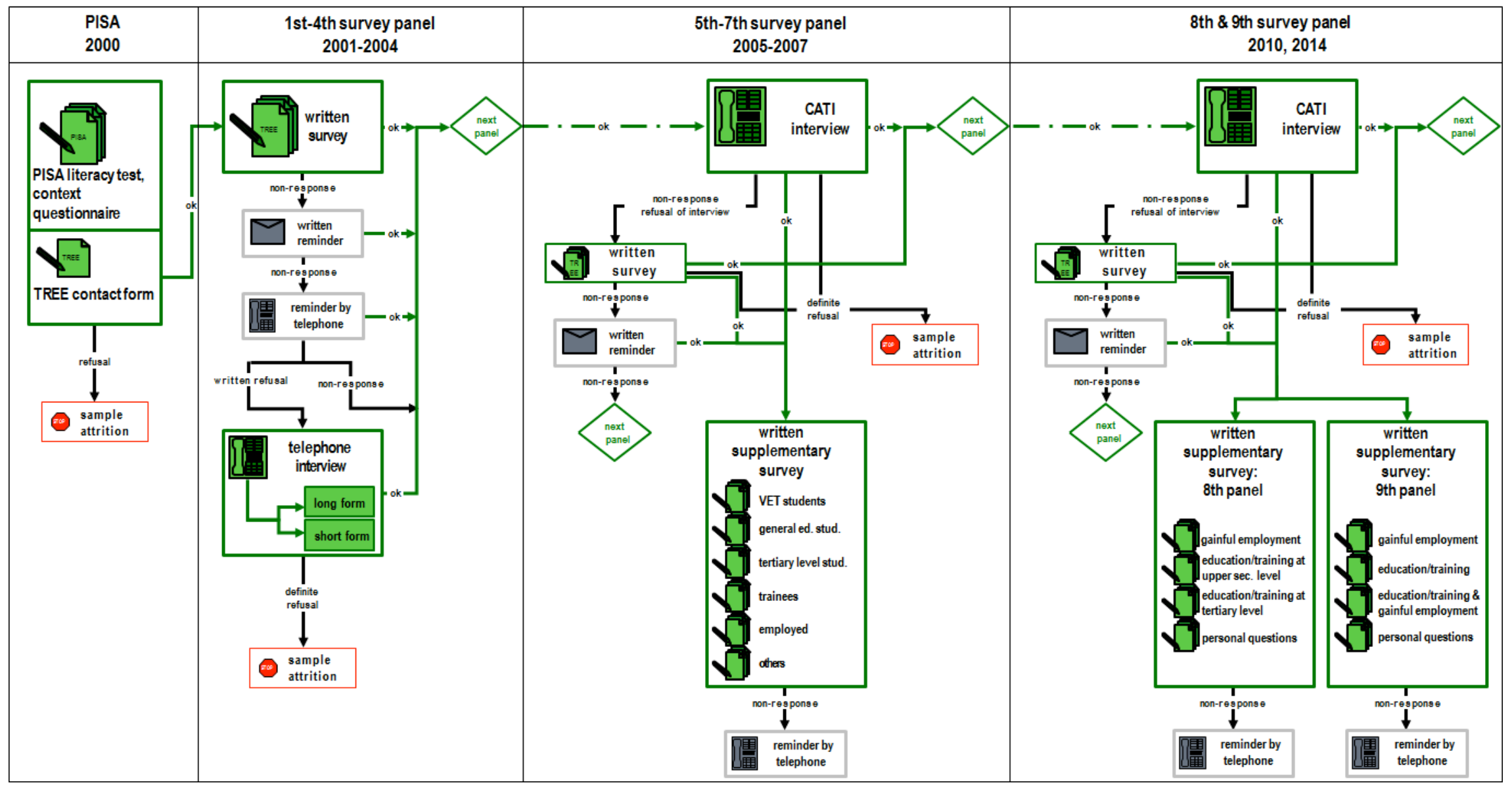




\section{Sample, response rates and weighting}

As mentioned above, TREE1 is based on the Swiss PISA 2000 sample. PISA 2000 minimal sampling standards required national samples of 5,000 to 6,000 students at age 15 (Adams \& Wu, 2002). Switzerland by far exceeded these standards. The Swiss PISA 2000 sample size exceeded 13,000 (approximately one-sixth of the relevant student population) owing to a substantial oversampling of ninth graders and students from selected cantons (for detail, see Renaud, 2002). As PISA 2000 basically granted anonymity to respondents, TREE had to ask for their consent to be contacted and for their contact data (e.g., mailing address, email address, phone number). Rates of consent varied considerably across survey regions. Thus, whereas in Italian-speaking Switzerland $81 \%$ of the PISA sample gave their consent (and their contact data) to participate in TREE, response rates were much lower in other cantons (e.g., 32\% in Zurich; Sacchi, 2011). Overall, this resulted in a relatively low rate of consent of only $54 \%$.

Throughout the first seven panel waves from 2001 to 2007, TREE1 achieved wave-specific response rates of $85-89 \%$ (see table 1 ). These rates are remarkably high considering the heterogeneous sample structure. In waves eight and nine, response was considerably lower $(75 \%$ and $71 \%$, respectively); however, given the broadening of the survey interval from one to three to four years, the 2010 and 2014 response rates can also be considered satisfactory. Cumulative response did not dramatically decrease between 2010 and 2014 (from $54 \%$ to $50 \%$ ). After nine follow-up surveys, the gross sample size that can be contacted to participate in the next survey panel in 2019 is still approximately 4,400 .

Table 1: TREE1 response rates, 2000-2014

\begin{tabular}{lcccccccccc} 
Survey year & $\mathbf{2 0 0 0}$ & $\mathbf{2 0 0 1}$ & $\mathbf{2 0 0 2}$ & $\mathbf{2 0 0 3}$ & $\mathbf{2 0 0 4}$ & $\mathbf{2 0 0 5}$ & $\mathbf{2 0 0 6}$ & $\mathbf{2 0 0 7}$ & $\mathbf{2 0 1 0}$ & $\mathbf{2 0 1 4}$ \\
\hline $\begin{array}{l}\text { Samples (N) } \\
\begin{array}{l}\text { TREE gross } \\
\text { sample }\end{array}\end{array}$ & $11,710^{*}$ & 6,343 & 5,944 & 5,609 & 5,345 & 5,060 & 4,852 & 4,659 & 4,571 & 4,402 \\
$\begin{array}{l}\text { Responses } \\
\text { Response rates (\%) }\end{array}$ & $6,343^{* *}$ & 5,528 & 5,206 & 4,877 & 4,679 & 4,506 & 4,133 & 3,979 & 3,423 & 3,142 \\
$\begin{array}{l}\text { \% of wave } \\
\text { of 2001 }\end{array}$ & $54 \%$ & $87 \%$ & $88 \%$ & $87 \%$ & $88 \%$ & $89 \%$ & $85 \%$ & $85 \%$ & $75 \%$ & $71 \%$ \\
\begin{tabular}{l} 
survey \\
\hline
\end{tabular} & & $82 \%$ & $77 \%$ & $74 \%$ & $71 \%$ & $65 \%$ & $63 \%$ & $54 \%$ & $50 \%$ \\
\hline
\end{tabular}

* Sample base (after exclusion of participants not satisfying TREE sampling selection criteria; see the "Overall design" section).

** PISA respondents consenting to participate in the TREE panel survey (including provision of contact data).

In the first two years, $80 \%$ of the respondents completed the written questionnaire (see table 2). The proportion of returned questionnaires dropped to roughly $70 \%$ during the third and fourth survey panels, whereas the number of responses by way of short telephone interviews rose sharply. After the changes in survey design described in the "TREE1 survey design" section, the share of the sample that responded to the full survey (CATI or basic written questionnaire plus supplementary questionnaire) remained at $70 \%$. Between one-fifth and one-sixth participated by telephone only. Thus, TREE achieved an exceptionally high level of overall response by offering potential dropouts alternative and/or streamlined modes of participation. The high overall response rate confirms the importance TREE gave to sample maintenance (see the "Measures to increase panel retention" section above). 
Table 2: TREE1 response rates from 2001 to 2014 by type of response

\begin{tabular}{|c|c|c|c|c|c|c|c|c|c|}
\hline Survey year & 2001 & 2002 & 2003 & 2004 & 2005 & 2006 & 2007 & 2010 & 2014 \\
\hline Written questionnaire & $80 \%$ & $80 \%$ & $71 \%$ & $71 \%$ & & & & & \\
\hline $\begin{array}{l}\text { Telephone questionnaire, } \\
\text { long form }\end{array}$ & $6 \%$ & $4 \%$ & $3 \%$ & $5 \%$ & & & & & \\
\hline $\begin{array}{l}\text { Telephone questionnaire, } \\
\text { short form }\end{array}$ & $2 \%$ & $3 \%$ & $13 \%$ & $12 \%$ & & & & & \\
\hline $\begin{array}{l}\text { CATI/basic questionnaire } \\
\text { and supplementary } \\
\text { questionnaire } *\end{array}$ & & & & & $71 \%$ & $69 \%$ & $68 \%$ & $60 \%$ & $59 \%$ \\
\hline $\begin{array}{l}\text { CATI/basic questionnaire } \\
\text { only* }\end{array}$ & & & & & $19 \%$ & $16 \%$ & $17 \%$ & $15 \%$ & $12 \%$ \\
\hline $\begin{array}{l}\text { No response, single wave } \\
\text { refusal (remaining in the } \\
\text { sample) }\end{array}$ & $7 \%$ & $8 \%$ & $10 \%$ & $8 \%$ & $9 \%$ & $13 \%$ & $13 \%$ & $23 \%$ & $23 \%$ \\
\hline $\begin{array}{l}\text { No response (sample } \\
\text { attrition) }\end{array}$ & $6 \%$ & $5 \%$ & $3 \%$ & $4 \%$ & $2 \%$ & $2 \%$ & $2 \%$ & $2 \%$ & $5 \%$ \\
\hline $\begin{array}{l}\text { Total } N \text { (=100\%; } \\
\text { gross sample) }\end{array}$ & 6,343 & 5,944 & 5,609 & 5,345 & 5,060 & 4,852 & 4,659 & 4,571 & 4,402 \\
\hline
\end{tabular}

As in any panel survey, sample attrition has varied substantially by a number of sociodemographic, socio-economic and academic performance characteristics. For instance, attrition rates among low achievers, young men and migrants are substantially above average (Sacchi 2011:13ff.). As information about both respondents and non-respondents is abundant in our case, such biases can be modelled and corrected in fair approximation. Moreover, it is advantageous that non-response was very low in the baseline survey (PISA 2000: approximately 5\%). All information about respondents and survey conditions obtained in the baseline survey are thus available for correcting for the high level of non-response with regard to respondents' consent to join the TREE panel. In addition, all the information from any given TREE survey wave can be used to correct for non-response biases that occur in subsequent waves (see Sacchi 2011 for more detailed information).

\section{Demographic features}

To describe some characteristics of the TREE1 sample, table 3 provides the main demographic features in 2000 (baseline survey) and 2014 (ninth panel wave sample). We can see that fourteen years after leaving compulsory school, the sample size still allows for analysis of a wide range of subgroups with regard to education, occupation, family and other situations. Note that weights should be taken into account to ensure representativeness. 
Table 3: Demographic features of TREE1 sample in 2000 ( $\sim 15$ years old) and 2014 ( 29 years old)

\begin{tabular}{|c|c|c|c|}
\hline \multicolumn{2}{|c|}{ TREE1 baseline survey, 2000} & $\begin{array}{c}N \\
\text { (unweighted) }\end{array}$ & $\begin{array}{c}\% \\
\text { (unweighted) }\end{array}$ \\
\hline \multicolumn{2}{|c|}{ Total } & 6,343 & 100 \\
\hline \multirow[t]{2}{*}{ Gender } & Female & 3,440 & 54 \\
\hline & Male & 2,903 & 46 \\
\hline \multirow[t]{4}{*}{ Year of birth } & 1983 & 757 & 12 \\
\hline & 1984 & 3,399 & 54 \\
\hline & 1985 & 2,052 & 32 \\
\hline & Other years & 111 & 2 \\
\hline \multirow{3}{*}{$\begin{array}{l}\text { Academic track } \\
\text { attended at lower } \\
\text { secondary level }\end{array}$} & Extended requirements & 4,358 & 68 \\
\hline & Basic requirements & 1,626 & 26 \\
\hline & No formal grouping & 357 & 6 \\
\hline \multirow{6}{*}{$\begin{array}{l}\text { PISA reading literacy } \\
\text { score }\end{array}$} & Very low & 222 & 4 \\
\hline & Low & 587 & 9 \\
\hline & Medium low & 1,315 & 21 \\
\hline & Medium high & 2,144 & 34 \\
\hline & High & 1,555 & 25 \\
\hline & Very high & 514 & 8 \\
\hline \multirow[t]{3}{*}{ Migration background } & Swiss native* & 3,776 & 60 \\
\hline & Second generation** & 1,560 & 25 \\
\hline & Migrant*** & 900 & 14 \\
\hline \multirow[t]{3}{*}{ Language region } & German & 2,970 & 47 \\
\hline & French & 2,540 & 40 \\
\hline & Italian & 833 & 13 \\
\hline \multirow[t]{2}{*}{ Rural vs. urban area } & Rural & 2,072 & 33 \\
\hline & Urban & 4,271 & 67 \\
\hline \multicolumn{4}{|c|}{ TREE1 9th panel wave sample, 2014 ( 29 years old) } \\
\hline \multicolumn{2}{|c|}{ Total } & 3,142 & 100 \\
\hline \multirow{3}{*}{$\begin{array}{l}\text { Educational } \\
\text { attainment }\end{array}$} & Compulsory & 87 & 3 \\
\hline & Secondary & 1,161 & 37 \\
\hline & Tertiary & 1,881 & 60 \\
\hline \multirow[t]{3}{*}{ Gainful occupation } & Full-time work ( $\geq 90 \%)$ & 2,074 & 66 \\
\hline & Part-time work (<90\%) & 712 & 23 \\
\hline & Other situation & 356 & 11 \\
\hline \multirow[t]{3}{*}{ Marital status } & Single & 2,202 & 70 \\
\hline & Married & 893 & 28 \\
\hline & Other status & 46 & 1 \\
\hline \multirow[t]{2}{*}{ Parenthood } & Yes & 767 & 24 \\
\hline & No & 2,374 & 76 \\
\hline
\end{tabular}




\section{Theoretical and conceptual framework}

TREE collects data on education, employment and family transitions within an interdisciplinary and general life-course research framework (Baltes, 1990; Blossfeld \& von Maurice, 2011; Fend, Berger $\&$ Grob, 2009) by taking into account the complex interaction of objective and subjective factors at the individual, organisational/institutional and societal levels. Life course approaches are held to be promising when it comes to disentangling effects of age, cohort and temporal effects (Baltes, 1990; Elder, 1994; Levy, Ghisletta, Le Goff, Spini \& Widmer, 2005). Moreover, they build conceptual bridges between sociological and psychological issues as well as between individual development and social structures (Blossfeld \& von Maurice, 2011). TREE features a broad variety of concepts, thus making itself an excellent tool for interdisciplinary research across disciplines such as sociology, educational sciences, psychology, economics, health and life-course studies (see TREE $2016 \mathrm{~b}$ for further information). The insight gained with regard to the circumstances and mechanisms of transitions from initial education to middle adulthood provide sound empirical evidence for specific educational, labour market and social policy measures.

With regard to education, the concepts and scales adopted in the TREE surveys refer to sociological theories of status reproduction on the one hand (Bourdieu, 1977, 1984; Bowles \& Gintis 1976; Willis 1977; for an overview on the current state of research, see Draelants \& Ballatore, 2014 or Winkle-Wagner, 2010) and of decision-making in rational choice approaches (Baumert \& Schümer, 2002; Blossfeld \& Shavit, 1993; Boudon, 1974; Breen \& Goldthorpe 1997; Ramseier \& Brühwiler, 2003) on the other. These theories model the effects of social origin on educational decisions at each interface of the education system. In the fields of psychology and educational sciences, TREE draws on developmental theories that deal with educational and occupational socialisation (Heinz, 1984; Ulich, 1991) as well as with the ways in which youths cope with, in Bronfenbrenner's (1979) terms, "ecological transitions". Other concepts used to explain educational pathways derive from theories of self-concept (Eccles, Vida \& Barber, 2004; Greve, 2000), institutional resources and constraints (which may lead to individual stress; Semmer, 1997), wellbeing (e.g., self-esteem, depression, attitude towards life, personal values; see Fischer, 2006; Hascher, 2004) and critical life events (e.g., relocation, divorce/separation of parents, illness, death of a relative; see table 4 and Filipp, 1995).

When it comes to analysing labour market entry, TREE relies on concepts and instruments used by classical human capital theory (Becker, 1964), signal(ling) and social capital theories (Coleman, 1988, 1990; Spence, 1973), theories of discrimination (Arrow, 1994; Becker, 1957/1971) and school-to-work transition models based on labour market economics (OECD, 2000; Ryan, 2001).

On the basis of these theoretical frameworks, TREE1 has been designed to collect data on postcompulsory education life trajectories (see table 4). First, it provides highly detailed information on academic skills and achievement at the end of compulsory school (based on the PISA 2000 survey) as well as in-depth information on post-compulsory educational pathways. In addition, data on detailed individual characteristics such as gender, social and migration background and place of residence as well as psychological and psycho-social variables and scales such as personal values with regard to family, education and work, psycho-social resources (self-esteem, positive attitude towards life and coping) and social support are available. This allows researchers to analyse the influence of compulsory educational outcomes, of schooling contexts and of individual characteristics on later educational, occupational and family outcomes and/or trajectories.

Second, TREE1 provides highly detailed longitudinal information on gainful occupation. The new 2016 data release includes a data file on month-by-month episodes of gainful employment that covers an observation period of twelve years (2003 to 2014). Employment data include type of employment (hours of work per week, type of employment contract, wage), characteristics of the job and of the work team, challenges and resources at the workplace, subjective assessment of gender and equal opportunity, social support and job satisfaction (TREE 2016b). It further allows one to link job career development to both macro conditions of employment and subjective assessment of the individual job situation.

Third, TREE offers comprehensive longitudinal information on family life (parenting, household composition, financial situation of the household, 
relocations) and civil status that opens promising research opportunities on interdependence between life domains.

The instrumentation of the TREE survey(s) is guided by the principle of comparability to previous waves and between cohorts. Consequently, adjustments of the survey's instruments are only made to explore the sample's progression into new biographical phases or to enhance research opportunities in terms of international comparability (see "TREE1 survey design" and "Call for instruments" sections). In the first phase (from 2001 to 2003), education and employment transition patterns at the interface of compulsory school to upper secondary education (or other activities) were at the centre of attention. During this first stage, the main focus was on the underlying reasons for typical trajectories as well as consequences of irregular or critical educational careers, particularly with regard to premature dropout (young people who fail to graduate from a post-compulsory education or training programme). During the second stage of TREE (from 2004 to 2007), the study centred on the transition from upper secondary-level education (be it vocational or general) to working life or tertiary education. In the third phase from 2008 to 2014, it was particularly important to capture in detail individual integration into the labour market, education and continuing education in mid-career as well as family transitions.

Table 4 shows the main concepts employed by TREE. A separate document titled Concepts \& Scales (TREE 2016a) and the codebooks specify in detail the concepts and items that have been used in the nine panel waves carried out so far. All methodological documents necessary for data use are included in the TREE1 public use dataset package. 
Table 4: Concepts and scales, TREE1, 2001-2014

Education/training

Description of education/training situation, certifications and pathways

- Education episodes (type of education/traineeship, starting/end date, change of curriculum)

- Description of education/training context (size of training firms, commuting distance to school/firm, skills/competences of trainers, teachers and supervisors, etc.)

- Certifications (types of certification, date of certification)

Challenges and resources in education and vocational education and training (VET) traineeship

- Caused by education/training conditions, by environment, etc.

- Freedom of action, cooperation, comprehensiveness of tasks, variety of tasks, etc.

Learning styles

- Concentration, willingness to make an effort, etc.

Equal opportunity in schools and VET training firms

- Gender and nationality

Satisfaction with regard to education/training

- In general, with the school/training firm, with the class, etc.

Employment

Description of employment situation and working conditions

- Employment episodes (type of employment, starting/end date)

- Terms of employment (employment status, working hours, salary, position in the hierarchy, type of employment contract, commuting distance, etc.)

- Structural data on employers (firm size, economic sectors, etc. [added from third-party sources])

Challenges and resources at the workplace

- Caused by work organisation, by working environment, etc.

- Freedom of action, cooperation, comprehensiveness of tasks, variety of tasks, etc.

Job search and application strategies

- Job search strategies, application activities, duration of job search, etc.

Equal opportunities of employer

- Gender, nationality, skills, certifications

Satisfaction with regard to work and profession

- With professional career, employing firm, etc.

Other life situations and activities

\section{Description of other life situations}

- Not in education, employment or training (NEET) episodes (type of activity, starting/end date)

- Desired activity

- Family situation/status (housing situation, civil status, children, nationalities/naturalisation, financial situation, etc.)

Significant life events

- With regard to education, work and private life (relocation, separation, divorce, illness, death)

Personal characteristics and values

- Persistence, self-efficacy, coping ability, ambition, etc.

- Value orientation (partnership/family, leisure, work)

Health and wellbeing

Social integration and participation

Social relations and social support with regard to education/training

- Privately, at school and in VET training firms

Social relations and social support with regard to work

- Privately and colleagues at work

Relationships

Societal and cultural participation 


\section{Call for instruments}

On several occasions TREE has launched calls for instruments. These invited researchers to propose additional concepts, scales, modules or single items that might enhance the analytic potential and (inter)national comparability of the TREE dataset. This approach ensures that concepts and scales provide answers to current and relevant research questions from the scientific community in a variety of disciplines. Furthermore, involving the scientific community in the instrumentation process ensures intensive use of the collected data (see, e.g. Bertogg \& Szydlik, 2016; Gauthier \& Gianettoni, 2013; Keller, 2013 for the use of items and scales proposed on the basis of calls for instruments).

The selection of instruments has been made by the project's interdisciplinary scientific team in consultation with the TREE Advisory Board. TREE has prioritised instrument proposals that promise to foster international comparative research and given preference to validated, widely used instruments with a good theoretical foundation and a concrete analytical design. Instrument selection was further based on interdisciplinary relevance, feasibility of implementation and academic costbenefit analysis. The response to these calls was extremely gratifying. Experienced researchers from a variety of disciplines have submitted a large number of proposals, and 10 to $20 \%$ of the instruments used in the ninth TREE1 survey wave (2014) have been improved or added in the process. On the basis of this encouraging experience, TREE will continue to launch calls for instruments in preparation for further survey waves.

\section{Data use}

The new 2016 data release of TREE1 (20002014) is available free of charge for researchers and students on the Swiss Centre of Expertise in the Social Sciences FORS website (www.forscenter.ch). It includes the PISA 2000 dataset (baseline survey), nine wave-specific datasets (2001-2014) as well as new datasets that cover several waves (for instance, month-by-month job episodes or educational certificates). Extensive data documentation is available in three languages: English, French and German (see TREE 2016b for more detail). The 2016 data release thus offers promising new opportunities for highly detailed analysis of early adulthood transitions (up to age 29) and on the interplay between education and professional careers (or other life domains such as health, family situation and significant life events). In addition, international comparative research could be further developed to study the impact of economic, institutional or social policy as well as other contexts on individual life courses (see, e.g. Buchmann, Kriesi, Koomen, Imdorf \& Basler, 2016; Imdorf, Helbling \& Inui, forthcoming; Imdorf \& Hupka-Brunner, 2015; Kamanzi, Guégnard, Imdorf, Koomen \& Murdoch, 2014; Murdoch, Guégnard, Griga, Koomen \& Imdorf, 2016; Murdoch et al., 2017; Picot \& Hou, 2013). To date, around 270 researchers and students from national and international institutions across a multitude of disciplines have been working with the TREE1 data. Their analyses have led to over 200 publications that address a wide range of issues such as educational inequality (Buchmann et al., 2016), gendered education and labour market pathways (Imdorf \& Hupka-Brunner, 2015), the particular role that VET plays for labour market entry in Switzerland (Müller \& Schweri, 2015; Helbling \& Sacchi, 2014), the impact of discontinuous pathways on later education and labour market outcomes (Sacchi \& Meyer, 2016) and the scarring effect of precarious employment at labour market entry on occupational careers of young workers (Buchs \& Helbling, 2016; Helbling \& Sacchi, 2014; Helbling, 2017). ${ }^{\text {xii }}$

\section{Conclusions}

The latest TREE1 data release, freely available online (www.forscenter.ch), offers extensive analysis opportunities for life course research on a large Swiss cohort sample over an observation span of roughly 15 years (ages 15-29). TREE employs a longitudinal and comprehensive approach at the intersection of various disciplines, thereby providing extensive opportunities to analyse life transitions in all their complexity at the individual, organisational/institutional and societal levels as well as their interaction. In summary, the following particular features of the TREE dataset enhance its analytic power for the scientific community:

Given the ever-increasing duration of formal education in knowledge-based societies, TREE's long observation span ensures that all school-towork transitions are covered, including those of students in extended study programmes at the tertiary level. 
- Linking the TREE1 panel to the Swiss PISA 2000 sample not only provides the study with an (abundantly contextualised) standardised basic skills measure at its baseline. It also allows for cross-national comparative studies with datasets of other countries that have done the same (for examples of comparative analyses, see Picot \& Hou, 2013; Murdoch et al. 2016). xiii $^{\text {in }}$

- Tight intervals of observation, particularly during the first seven years (yearly panels).

- The detailed, month-by-month episodic data on education and employment renders the data particularly suitable for thorough analysis of school-to-work transition, labour market entry and medium- to long-term career development (for examples for this kind of analysis, see Imdorf \& Hupka-Brunner, 2015; Müller \& Schweri, 2015).

- The availability of abundant context data allow for complex modelling of factors that influence the observed pathways and transitions.

Broad multi-disciplinary instrumentation allows for analysis of a particularly wide range of research questions and for interdisciplinary analyses.

Individual data on youth passing through the highly decentralised, VET-orientated Swiss education system with its high variability of institutional arrangements for school-to-work transitions provide a kind of "life-sized" laboratory for comparative research at both the (sub)national and cross-national levels.

From a critical perspective, it should not be withheld that the TREE data are also subject to some limitations. One of the most substantial among them is that cohort observation starts at a later than ideal time when taking into account some of the crucial features of the Swiss education system. Given the early and pronounced tracking of the country's lower secondary education, cohort observation should begin earlier, ideally before the transition from primary to lower secondary education (i.e. at approximately 12 years of age at the latest). Starting the panel survey as late as the ninth grade means that for a large part of the sample crucial educational decisions in the early phase of respondents' educational careers have already taken place and can only be assessed retrospectively. We have seriously attempted to remedy this limitation by advancing the launch of the second cohort (TREE2) to an earlier age. However, we have not been granted the funds to do so, unfortunately. This flaw in TREE's study design is somewhat mitigated by the fact that in recent years several cohort studies investigating earlier phases of Swiss educational careers have been launched. ${ }^{\text {xiv }}$

A second major limitation is that the available data are basically restricted to standardised selfreported student data. Data from other sources (such as teachers or parents) as well as qualitative data or repeated skills measures are not available.

As mentioned earlier, another survey panel for the first TREE cohort TREE1 is planned for 2019. By then, respondents will be 34 years of age on average. Family formation will have initiated for a large part of the sample, and we intend to integrate the respondents' children into the survey, thus extending the scope of the study to the next generation. We expect data from this panel survey to be available by early 2021. After the launch of the second cohort in 2016, TREE will soon provide the first opportunities for cross-cohort research. We expect to release the first waves (baseline and first follow-up panel) of TREE2 data in early 2019.

\section{References}

Adams, R. \& Wu, M. (2002). PISA 2000 Technical Report. OECD.

Arrow, K. J. (1994). The Theory of Discrimination. In D. B. Grusky (ed.), Social Stratification (pp. 604-606). Boulder: Westview Press.

Baltes, P. (1990). Entwicklungspsychologie der Lebensspanne: Theoretische Leitsätze. Psychologische Rundschau, (41), 1-24.

Baumert, J. \& Schümer, G. (2002). Familiäre Lebensverhältnisse, Bildungsbeteiligung und Kompetenzerwerb im nationalen Vergleich. In J. Baumert, C. Artelt, E. Klieme, M. Neubrand, M. Prenzel, U. Schiefele, W. Schneider, K.-J. Tillmann \& M. Weiß (eds.), PISA 2000 - Die Länder der Bundesrepublik Deutschland im Vergleich (pp. 159-202). Opladen: Leske + Budrich. 
Becker, G. S. (1964). Human Capital: A Theoretical and Empirical Analysis with Special Reference to Education. New York and London: Columbia University Press.

Becker, G. S. (1957/1971). The Economics of Discrimination. Chicago: University of Chicago Press.

Bergman, M., Hupka-Brunner, S., Keller, A., Meyer, T. \& Stalder, B. E. (eds.). (2011). Youth Transitions in Switzerland: Results from the TREE Panel Study. Zurich: Seismo.

Bertogg, A. \& Szydlik, M. (2016). The Closeness of Young Adults' Relationships with Their Parents. Swiss Journal of Sociology, 42(1), 41-59. https://doi.org/10.1515/sjs-2016-0003

Blossfeld, H.-P. \& Shavit, Y. (1993). Persisting Barriers. Changes in Educational Opportunities in Thirteen Countries. In Y. Shavit \& H.-P. Blossfeld (eds.), Persistent Inequality: Changing Educational Attainment in Thirteen Countries (pp. 1-23). San Francisco: Westview-Press.

Blossfeld, H.-P. \& von Maurice, J. (2011). Education as a Lifelong Process. Zeitschrift für Erziehungswissenschaft, 14(2), 19-32. https://doi.org/10.1007/s11618-011-0179-2

Boudon, R. (1974). Education, Opportunity, and Social inequality: Changing Prospects in Western Society. New York: John Wiley.

Bourdieu, P. (1977). Cultural Reproduction and Social Reproduction. In J. Karabel (ed.), Power and Ideology in Education (pp. 487-511). New York: Oxford University Press.

Bourdieu, P. (1984). Distinction: A Social Critique of the Judgment of Taste. Cambridge, MA: Harvard University Press.

Bowles, S. \& Gintis, H. (1976). Schooling in Capitalist America. Educational Reform and the Contradictions of Economic Life. New York: Basic Books.

Breen, R. \& Goldthorpe, J. H. (1997). Explaining Educational Differentials: Towards a Formal Rational Action Theory. Rationality and Society, 9(3), 275-305. https://doi.org/10.1177/104346397009003002

Bronfenbrenner, U. (1979). The Ecology of Human Development: Experiments by Nature and Design. Cambridge, MA: Harvard University Press.

Buchmann, M., Kriesi, I., Koomen, M., Imdorf, C. \& Basler, A. (2016). Differentiation in Secondary Education and Inequality in Educational Opportunities: The Case of Switzerland. In H.-P. Blossfeld, S. Buchholz,J. Skopek, \& M. Triventi (eds.), Models of Secondary Education and Social Inequality - An International Comparison (pp. 111-128). Cheltenham: Edward Elgar. https://doi.org/10.4337/9781785367267.00016

Buchs, H. and Helbling, L.A. (2016). Job Opportunities and School-to-Work Transitions in Occupational Labour Markets. Are Occupational Change and Unskilled Employment after Vocational Education Interrelated? Empirical Research in Vocational Education and Training, 8(17). https://doi.org/10.1186/s40461-016-0044-x

Coleman, J. S. (1988). Social Capital in the Creation of Human Capital. American Journal of Sociology, 94, S95-S120. https://doi.org/10.1086/228943

Coleman, J. S. (1990). Foundations of Social Theory. Cambridge, MA and London: The Belknap Press of Harvard University Press.

Draelants, H. \& Ballatore, M. (2014). Capital culturel et reproduction scolaire. Un bilan critique. Revue française de pédagogie. Recherches en éducation, (186), 115-142. https://doi.org/10.4000/rfp.4430

Eccles, J. S., Vida, M. N. \& Barber, B. (2004). The Relation of Early Adolescents' College Plans and Both Academic Ability and Task-Value Beliefs to Subsequent College Enrollment. Journal of Early Adolescence, 24(1), 63-77. https://doi.org/10.1177/0272431603260919

Elder, G. H. J. (1994). Time, Human Agency, and Social Change: Perspectives on the Life Course. Social Psychology Quarterly, 57(1), 4-15. https://doi.org/10.2307/2786971

Fend, H., Berger, F. \& Grob, U. (eds.). (2009). Lebensverläufe, Lebensbewältigung, Lebensglück. Ergebnisseder Life-Studie. Wiesbaden: VS Verlag für Sozialwissenschaften. https://doi.org/10.1007/978-3-531-91547-0

Filipp, S.-H. (ed.). (1995). Kritische Lebensereignisse. Weinheim: Psychologie Verlags Union.

Fischer, L. (ed.). (2006). Arbeitszufriedenheit. Konzepte und empirische Befunde. Göttingen: Hogrefe.

Gauthier, J.-A. \& Gianettoni, L. (2013). Socialisation séquentielle et identité de genre liées à la transition de la formation professionnelle à l'emploi. Swiss Journal of Sociology, 39(1), 33-55. 
Greve, W. (2000). Psychologie des Selbst. Weinheim: Psychologie Verlags Union. Hascher, T. (2004). Wohlbefinden in der Schule. Münster: Waxman.

Heinz, W. R. (1984). Der Übergang von der Schule in den Beruf als Selbstsozialisation. Bremen: Universität. Helbling, L. A. (2017), Fixed-Term Jobs after Vocational Education and Training in Switzerland: Stepping Stone or Impediment? Swiss Journal of Sociology, 43(1), 89-113. https://doi.org/10.1515/sjs-20170005

Helbling, L. A. \& Sacchi, S. (2014). Scarring Effects of Early Unemployment among Young Workers with Vocational Credentials in Switzerland. Empirical Research in Vocational Education and Training, 6(12), 1-22. https://doi.org/10.1186/s40461-014-0012-2

Imdorf, C., Helbling, L. A. \& Inui, A. (forthcoming). Transition Systems and Non-Standard Employment in Early Career: Comparing Japan and Switzerland. Journal of Education and Work, 1-15.

Imdorf, C. \& Hupka-Brunner, S. (2015). Gender Differences at Labor Market Entry in Switzerland. In H.-P. Blossfeld et al. (eds.), Gender, Education and Employment. An International Comparison of School-toWork Transitions (pp. 267-286). Cheltenham/Northampton: Edward Elgar. https://doi.org/10.4337/9781784715038.00022

Kamanzi, P. C., Guégnard, C., Imdorf, C., Koomen, M. \& Murdoch, J. (2014). Démocratisation de l'enseignement supérieur et emprise des parcours : Comparaison entre la France, la Suisse et le Canada. Télescope, 20(2), p. 170-188.

Keller, A. C. (2013). Development of Job Resources and Personal Resources among Job Newcomers. Inaugural dissertation submitted to the University of Bern. Bern: Eigenverlag.

Levy, R., Ghisletta, P., Le Goff, J.-M., Spini, D. \& Widmer, E. (eds.). (2005). Towards an Interdisciplinary Perspective on the Life Course. Amsterdam \& Boston: Elsevier.

Müller, B. \& Schweri, J. (2015). How Specific Is Apprenticeship Training? Evidence from Inter-Firm and Occupational Mobility after Graduation. Oxford Economic Papers, 67(4), 1057-1077. https://doi.org/10.1093/oep/gpv040

Murdoch, J., Guégnard, C., Griga, D., Koomen, M. \& Imdorf, C. (2016). How Do Second-Generation Immigrant Students Access Higher Education? The Importance of Vocational Routes to Higher Education in Switzerland, France, and Germany. Swiss Journal of Sociology, 42(2), 245-263.

Murdoch, J., Guégnard, C., Koomen, M., Imdorf, C. \& Hupka-Brunner, S. (2014). Pathways to Higher Education in France and Switzerland: Do Vocational Tracks Facilitate Access to Higher Education for Immigrant Students? In G. Goastellec \& F. Picard (eds.), Higher Education in Societies. A Multi Scale Perspective (pp. 149-169). Rotterdam, Boston \& Taipei: Sense Publishers. https://doi.org/10.1007/978-94-6209-746-9_10

Murdoch, J., Guégnard, C., Koomen, M., Imdorf, C., Kamanzi, C. \& Meyer, T. (2017). Pathways Fostering Mobility to Higher Education for Vulnerable Immigrants in France, Switzerland and Canada. European Journal of Higher Education, 7(1), 29-42. https://doi.org/10.1080/21568235.2017.1254918

OECD (1999). Thematic Review of the Transition from Initial Education to Working Life. Switzerland. Country Note. Paris: OECD.

OECD (2000). From Initial Education to Working Life. Making Transitions Work. Paris: OECD.

Picot, G. \& Hou, F. (2013). Why Immigrant Background Matters for University Participation: A Comparison of Switzerland and Canada. International Migration Review, 47(3), 612-642. https://doi.org/10.1111/imre.12038

Ramseier, E. \& Brühwiler, C. (2003). Herkunft, Leistung und Bildungschancen im gegliederten Bildungssystem: Vertiefte PISA-Analyse unter Einbezug der kognitiven Grundfähigkeiten. Schweizerische Zeitschrift für Bildungswissenschaften, 25(1), 23-58.

Renaud, A. (2002). Plans d'échantillonnage pour PISA 2000 en Suisse. Rapport de méthodes PISA. Neuchâtel: Office fédéral de la statistique.

Ryan, P. (2001). The School-to-Work Transition: A Cross-National Perspective. Journal of Economic Literature, 39(1), 34-92. https://doi.org/10.1257/jel.39.1.34 
Sacchi, S. (2011). Construction of TREE Panel Weights. Documentation for the Panel Waves from 2000 to 2010. Basel and Zurich: TREE \& cue sozialforschung.

Sacchi, S. \& Meyer, T. (2016). Übergangslösungen beim Eintritt in die Schweizer Berufsbildung: Brückenschlag oder Sackgasse? Swiss Journal of Sociology, 42(1), 9-39.Scharenberg, K., HupkaBrunner, S., Meyer, T. \& Bergman, M. (eds.). (2016). Transitions in Youth and Young Adulthood: Results from the Swiss TREE Panel Study. Volume 2. Zurich: Seismo

Scharenberg, K., Rudin, M., Müller, B., Meyer, T. \& Hupka-Brunner, S. (2014). Education Pathways from Compulsory School to Young Adulthood: The First Ten Years. Results of the Swiss Panel Survey TREE, Part I. Basel: TREE.

Semmer, N. (1997). Stress. In H. Luczak \& W. Volper (eds.), Handbuch Arbeitswissenschaft. Stuttgart: Schäfer-Pöschel Verlag.

Spence, M. (1973). Job Market Signalling. Quarterly Journal of Economics, 87, 355-379. https://doi.org/10.2307/1882010

TREE (ed.) (2016a). Concepts and Scales. Survey Waves 1 to 9, 2001-2014. Bern: TREE.

TREE (ed.) (2016b). Documentation on the first TREE cohort (TREE1), 2000-2016. Bern: TREE.

Ulich, K. (1991). Schulische Sozialisation. In K. Hurrelmann \& D. Ulich (eds.), Neues Handbuch der Sozialisationsforschung (pp. 378-396). Weinheim: Beltz.

Willis, P. (1977). Learning to Labor. How Working Class Kids Get Working Class Jobs. New York: Columbia University Press.

Winkle-Wagner, R. (2010). Cultural Capital: The Promises and Pitfalls in Education Research (ASHE Higher Education Report No. 36 (1)). Hoboken: ASHE.

\section{Endnotes}

i Online at http://www.tree.unibe.ch/index_eng.html.

ii Past and/or contemporary (multi-)cohort survey projects exist in some other countries, e.g., NLSY in the USA, NEPS in Germany, the British birth cohort studies and "Growing up" studies in Australia, Ireland, Scotland.

iii Other PISA follow-up studies started later in Australia (PISA 2003, 2006, 2009), the Czech Republic (PISA 2003), Denmark (PISA 2003), Uruguay (PISA 2003), the USA (PISA 2012) and Hong Kong (PISA 2012).

iv In Italian-speaking Switzerland school leavers from private schools were also included in the sample.

${ }^{v}$ Online at http://www.edk.ch/dyn/12928.php.

vi See the factsheet titled "Die Überprüfung der Erreichung der Grundkompetenzen (ÜGK) in der Schweiz. Haupterhebung 2016 Mathematik" at

http://grundkompetenzenmathematik.educa.ch/sites/default/files/20151104/uegk_2016_mathematik_factsheet_0.pd $\underline{f}$.

vii Computer-assisted telephone interviewing (CATI) would have been the method of choice. However, to insufficient funding in the early stage of the project forced TREE to switch to standardized written questionnaires as the less costly means of surveying. For TREE2, CATI was used in the first-wave survey, so we expect to obtain higher participation rates.

viii To further minimise attrition, a short form of the telephone interview (containing only few key questions on respondents' education and employment situation) was offered to those unwilling to reply to the long form.

${ }^{i x}$ The duration of CATI participation varies depending on individual situation and on the number of education, employment and other types of activities pursued since the previous panel wave.

${ }^{x}$ See Sacchi (2011) and TREE (2016b) for further information.

${ }^{x i}$ For an example (in German), see

http://www.tree.unibe.ch/ergebnisse/e305140/e305154/files307972/TREE_2014_Newsletter_8_de_ger.pdf.

The hand-written inserts are authentic comments and remarks from the respondents.

${ }^{x i i}$ For a complete list of publications, see www.tree.unibe.ch/results/publications/index_eng.html.

xiii See endnote iii.

${ }^{\text {xiv }}$ E.g., CoCon ("Competence \& Context", see http://www.cocon.uzh.ch ); Zurich longitudinal skills assessment ("Zürcher Lernstandserhebung", see

http://www.bi.zh.ch/internet/bildungsdirektion/de/unsere direktion/bildungsplanung/arbeitenundprojekte/lernstand. $\underline{\text { html). }}$ 